\title{
Enhanced Production of Cellulase by Escherichia coli Engineered with UV-mutated Cellulase Gene from Aspergillus niger UVMT-I
}

Qurat-ul-ain Daud, ${ }^{\text {a }}$ Zara Hamid, ${ }^{\text {a }}$ Tayyaba Sadiq, ${ }^{\text {a }}$ Asif Abbas, ${ }^{\text {a }}$ Saqib Hussain Hadri, ${ }^{\text {a }}$ Shahzad Hussain Shah, ${ }^{a}$ Muhammad Imran Mehmood Khan, ${ }^{\mathrm{b}}$ Muhammad Asghar, ${ }^{\mathrm{c}}$ and Muddassar Zafar ${ }^{\text {a,* }}$

\begin{abstract}
Enhanced cellulase production was studied with ultraviolet mutagenesis and the mutated cellulase gene in $E$. coli $\mathrm{DH} 5 \alpha$ was cloned for production under controlled conditions. Aspergillus niger inoculum was exposed to UV radiation for different time intervals. The UV exposure of $10 \mathrm{~min}$ to $A$. niger yielded $330 \mu \mathrm{mol} / \mathrm{min} / \mathrm{mg}$ specific activity. The mRNA of mutant $A$. niger yielding maximum enzyme activity was isolated and used for the synthesis of cDNA. The cDNA prepared from mRNA was used for the PCR amplification of mutated cellulase gene with primers designed on the basis of a cellulase gene database from $A$. niger. The amplified cellulase gene was cloned into $E$. coli DH5a followed by expression in E. coli BL21. The cellulase activity by wild type A. niger, $A$. niger UVMT-I, and recombinant $E$. coli was compared by analysis of variance test. The specific activity of cellulase by recombinant $E$. coli was maximum (441 $\mu \mathrm{mol} / \mathrm{min} / \mathrm{mg}$ ), followed by $A$. niger UVMT-I (330 $\mu \mathrm{mol} / \mathrm{min} / \mathrm{mg})$ and wild type $A$. niger $(96 \mu \mathrm{mol} / \mathrm{min} / \mathrm{mg})$.
\end{abstract}

Keywords: Enhanced activity; Mutagenesis; Cellulase; Aspergillus niger; E. coli

Contact information: a: Department of Biochemistry and Biotechnology, University of Gujrat, Gujrat, Pakistan; b: Department of Biochemistry, Faculty of Health sciences, Hazara University, Dhodial, Mansehra, Pakistan; c: National University of Medical Sciences, Rawalpindi, Pakistan;

*Corresponding author: muddassar.zafar@uog.edu.pk

\section{INTRODUCTION}

The genus Aspergillus includes filamentous fungi that are used in wide range of industrial applications. A. niger is a well-known member of this genus due to its importance in basic genetics research. Its natural habitat is a mesophilic environment, and it is found in plants, soil, and decaying organic matter. A. niger produces certain enzymes that are able to breach the highly tensile, complex mesh barrier of polysaccharides in cellulose, which is the first line of defense in any plant. The production or extraction of the cellulase enzyme with the help of $A$. niger is the most economical production route for cellulase. A. niger is abundant worldwide, and it is easy to manipulate for the production of cellulase (Rahman et al. 2017).

Cellulases are industrially important enzymes with applications in food, textiles, feed, detergents, paper, and bioethanol. Cellulases are used in commercial food processing, hydrolysis in drying processes, and detergent manufacturing. Cellulases are used in the pulp and paper and pharmaceutical industries. Cellulases are also used in the treatment of many ailments such as phytobezoars (Kramer and Pochapin 2012). Although cellulases are produced by a wide range of organisms, fungi have the ability to secrete 
extracellular cellulase. Because cellulases remove anti-nutritional factors from feed, they are used also in animal feed manufacturing (Singhania et al. 2010).

The production costs of cellulase enzymes have become increasingly difficult. Cellulase production would be more efficient if it were produced in bulk (Saini et al. 2015). Therefore, there is a well-established need for the improvement of production and activity of the cellulase enzyme. This can be performed using the rudimentary approach of introducing a mutation in the desired species, i.e., A. niger (Stein et al. 1989). This approach is known as random mutation, and it includes physical and chemical mutation. Treatment of $A$. niger with UV irradiation using different values of parameters such as time period and distance has been done by researchers, and cellulolytic activities have been enhanced (Van et al. 2011; Nahideh et al. 2017).

The physical mutation involves UV exposure. The UV rays generate oxidative mutations in the genetic material of A. niger (Yamada et al. 2017). In the present study, the activity of cellulase from an indigenous strain of $A$. niger has been enhanced through UV mutation.

\section{EXPERIMENTAL}

\section{Maintenance of $\boldsymbol{A}$. niger}

An indigenous strain of Aspergillus niger (Industrial Biotechnology Lab, Department of Biochemistry and Biotechnology, University of Gujrat, Pakistan) was grown on sporulation medium having $2 \%$ glucose, $2 \%$ agar, $0.05 \%$ magnesium sulphate, $0.05 \%$ calcium chloride, $0.02 \%$ ammonium sulphate, and $0.02 \%$ potassium hydrogen phosphate. The $\mathrm{pH}$ of the media was maintained at 5. The slants of A. niger were incubated at $33{ }^{\circ} \mathrm{C}$ for 6 days and then stored at $4{ }^{\circ} \mathrm{C}$ in the form of STAB cultures and at $-80{ }^{\circ} \mathrm{C}$ in the form of glycerol stock (Hadri et al. 2018, 2019).

\section{Ultraviolet Mutagenesis}

Ultraviolet mutagenesis was performed as previously described (Ramzan and Mehmood 2009; Rajeshkumar and Ilyas 2011) with slight modifications. A spore suspension was prepared in Vogel's media $\left(0.5 \%\right.$ trisodium citrate, $0.5 \% \mathrm{KH}_{2} \mathrm{PO}_{4}, 0.2 \%$ $\mathrm{NH}_{4} \mathrm{NO}_{3}, 0.4 \%\left(\mathrm{NH}_{4}\right)_{2} \mathrm{SO}_{4}, 0.02 \% \mathrm{MgSO}_{4}, 0.1 \%$ peptone, and $0.2 \%$ yeast extract). One $\mathrm{mL}$ of spore suspension was transferred into three sterilized empty Petri plates. The culture was exposed to a UV crosslinker that emitted $0.1 \mathrm{~J} / \mathrm{cm}^{2}$ radiation, and a distance of $15 \mathrm{~cm}$ was maintained from the lamp (Yamada et al. 2017). The UV treatment was performed for 20, 40, or $60 \mathrm{~min}$. The treated cultures were transferred into inoculum medium $(2 \%$ glucose, $2 \%$ carboxymethyl cellulose, $0.1 \%$ sorbose, $0.1 \%$ polyoxyethylene octyl phenyl ether (Triton X-100), $0.05 \% \mathrm{MgSO}_{4}, 0.05 \% \mathrm{CaCl}_{2}, 0.02 \%\left(\mathrm{NH}_{4}\right)_{2} \mathrm{SO}_{4}$, and $0.02 \% \mathrm{KH}_{2} \mathrm{PO}_{4}$ ) (Tolonen et al. 2015). Four flasks of inoculum media were prepared, one as control that was not exposed to the UV radiation. The other three flasks were exposed to $\mathrm{UV}$ radiation and incubated for 6 days at $33{ }^{\circ} \mathrm{C}$.

\section{Enzyme Assay}

The enzyme activity was determined following the method of Zhang et al. (2013). The cellulase activity was estimated by measuring the amount of reducing sugar secreted during the hydrolysis of carboxymethylcellulose (CMC). Five hundred microliters of CMC solution were added to $0.5 \mathrm{~mL}$ of crude extract. The mixture was 
incubated for $30 \mathrm{~min}$ at $45{ }^{\circ} \mathrm{C}$. After incubation, $3 \mathrm{~mL}$ of dinitrosalicyclic acid (DNS) reagent was added to reaction mixture and boiled for $5 \mathrm{~min}$. Twenty $\mathrm{mL}$ of distilled water were added, and the optical density was observed at $540 \mathrm{~nm}$. One unit of enzyme activity was defined as the amount of enzyme that released $1 \mu$ mole of reducing sugar as glucose per min under standard assay conditions. The A. niger mutant yielding maximum cellulase activity was selected for cloning.

\section{Cloning of Mutant Cellulase Gene in pTZ57R/T}

\section{RNA extraction}

Total fungal RNA was extracted using a commercially available kit (PureLink ${ }^{\mathrm{TM}}{ }{ }^{2}$ RNA Mini Kit, Invitrogen, Carlsbad, CA, USA). The extraction of RNA was confirmed by $0.8 \%$ agarose gel electrophoresis.

\section{Synthesis of cDNA and PCR amplification of the mutant cellulase gene}

The extracted total RNA of $A$. niger was converted into complementary DNA (cDNA) using a commercially available kit (Revert Aid First Strand cDNA Synthesis Kit, Thermo Scientific, Waltham, MA, USA). Forward (CAT ATG CAT CTA GGC AAC AGC TTG AGT TTG) and reverse primers (GGA TCC CTA CCC CAG ACT CGC) were designed with the help of the "Primer Premier 6.10" on the basis of the sequence of the cellulase gene of Aspergillus niger available at the NCBI website.

Template cDNA and respective primers were added in the master mixture, and the final reaction mixture was prepared up to $25 \mu \mathrm{L}$ per tube. Thermo-cycling conditions included an initial denaturation step at $95{ }^{\circ} \mathrm{C}$ for $5 \mathrm{~min}$, followed by 30 cycles of denaturation at $95{ }^{\circ} \mathrm{C}$ for $1 \mathrm{~min}$, annealing at $60{ }^{\circ} \mathrm{C}$ for 30 seconds, and extension at 72 ${ }^{\circ} \mathrm{C}$ for $2 \mathrm{~min}$, and a final extension temperature of $72{ }^{\circ} \mathrm{C}$ for $5 \mathrm{~min}$. A Qiagen gel extraction kit (Nottingham, England) was used to purify the amplified cellulase gene from the agarose gel after electrophoresis. The purified sample was stored at $-20{ }^{\circ} \mathrm{C}$.

\section{Ligation of mutant cellulase gene}

The purified cellulase gene was ligated into the pTZ57R/T (Waltham, MA, USA) cloning vector in buffer and DNA ligase. The ligation mixture was incubated at $22{ }^{\circ} \mathrm{C}$ overnight.

Transformation of E. coli DH5 $\alpha$ with $p T Z 57 R / T$ cloning vector

The heat shock method was used to transform $E$. coli DH5 $\alpha$ with cloned vector (Mancuso et al. 2002). DH5 $\alpha$ competent cells with $5 \mu \mathrm{L}$ ligated DNA mixture were incubated for $30 \mathrm{~min}$ on ice and subjected to heat shock at $42{ }^{\circ} \mathrm{C}$ for $2 \mathrm{~min}$. Cells were again transferred on ice for $2 \mathrm{~min}$. IPTG-XGAL-LB-agar-ampicillin plates were used to spread ligated mixture, and plates were incubated overnight at $37^{\circ} \mathrm{C}$.

\section{Screening of positive transformants}

The blue/white screening method was used to screen the mutant colonies. The positive transformants were selected and re-plated on the plates of IPTG-XGAL-LBagar-ampicillin (Zafar et al. 2014).

Plasmid DNA isolation (Mini-prep)

LB-ampicillin medium ( $5 \mathrm{~mL}$ ) was inoculated with colonies and incubated at 37 ${ }^{\circ} \mathrm{C}$ overnight with shaking. Approximately $1.5 \mathrm{~mL}$ of culture was centrifuged, and the 
pellet was resuspended in $100 \mu \mathrm{L}$ an ice-cold GTE solution (50 mM glucose; $25 \mathrm{Mm}$ Tris $\mathrm{Cl} ; 10 \mathrm{mM}$ EDTA, $\mathrm{pH}$ 8). Next, $200 \mu \mathrm{L}$ of a chilled $3 \mathrm{M}$ potassium acetate $(\mathrm{pH} 4.8)$ was added; the sample was vortexed for $2 \mathrm{sec}$ and placed on ice for $5 \mathrm{~min}$. The plasmid DNA was precipitated by phenol/chloroform extraction and resuspended in Tris EDTA buffer ( $\mathrm{pH} 8$ ). The miniprep plasmid DNA was visualized on $0.8 \%$ agarose gel.

\section{Restriction analysis of cloning vector}

pTZ57R/T plasmid was digested with NdeI and EcoRI using appropriate buffer (Fermentas, Waltham, MA, USA) to confirm the presence of the cloned cellulase gene. The reaction was carried out at $37^{\circ} \mathrm{C}$ for $1 \mathrm{~h}$. The result of digestion was observed on $0.8 \%$ agarose gel electrophoresis.

\section{Transformation of E. coli BL21 with Cell gene}

E.coli BL21 strain was transformed with cloned Cell gene through $p E T 22 b(+)$ expression vector and specific activity of secreted cellulase from recombinant E.coli was noted.

\section{Comparison of Cellulase Production}

After purification of enzyme through ammonium sulphate precipitation, dialysis and gel filtration chromatography, the production and specific activity of cellulase exhibited by wild type A. niger, A. niger UVMT-I, and recombinant E. coli was compared by the statistical analysis using analysis of variance (ANOVA). The highest activity was found through Duncan's multiple range test (DMRT).

\section{RESULTS AND DISSCUSSION}

\section{UV Mutagenesis of $A$. niger}

Three samples of $A$. niger spore suspension were exposed to the UV radiation for 10, 20, and $40 \mathrm{~min}$. The spore killing rate was $90 \%$ in the sample exposed to the UV radiations for $40 \mathrm{~min}$ because it showed unclear mycelium growth after inoculation. The spore suspension exposed to the UV radiation for 20 min showed very thin mycelium growth after incubation of liquid inoculum culture, indicating a $70 \%$ spore killing rate. However, the spore suspension exposed to the UV radiation for $10 \mathrm{~min}$ showed a clear and thick mycelium growth. Hence, the survival rate of colonies was maximum in culture exposed for $10 \mathrm{~min}$ to $\mathrm{UV}$ radiation.

\section{Cellulase activity after UV mutagenesis}

The cellulase assay was performed using CMC as substrate, releasing glucose as a by-product. The absorbance of glucose was noted at $540 \mathrm{~nm}$. The native (control) culture of $A$. niger that was not exposed to UV radiation exhibited $96 \mu \mathrm{mol} / \mathrm{min} / \mathrm{mg}$ of enzyme specific activity (Fig. 1). The samples exposed to UV for $10 \mathrm{~min}$ exhibited the maximum activity $(330 \mu \mathrm{mol} / \mathrm{min} / \mathrm{mg})$. The enzyme activity of the samples exposed for $20 \mathrm{~min}$ and $40 \mathrm{~min}$ exhibited enzyme activities of 60.7 and $37 \mu \mathrm{mol} / \mathrm{min} / \mathrm{mg}$, respectively. The comparison of cellulase activity after UV mutagenesis is shown in Fig. 1. Chand et al. (2005) reported progressive step-by-step treatment of UV at time intervals of 5, 10, 15, 20,25 , and 30 min on various fungal spores, which showed 1.9- and 2.1-fold enhanced cellulase activity. 


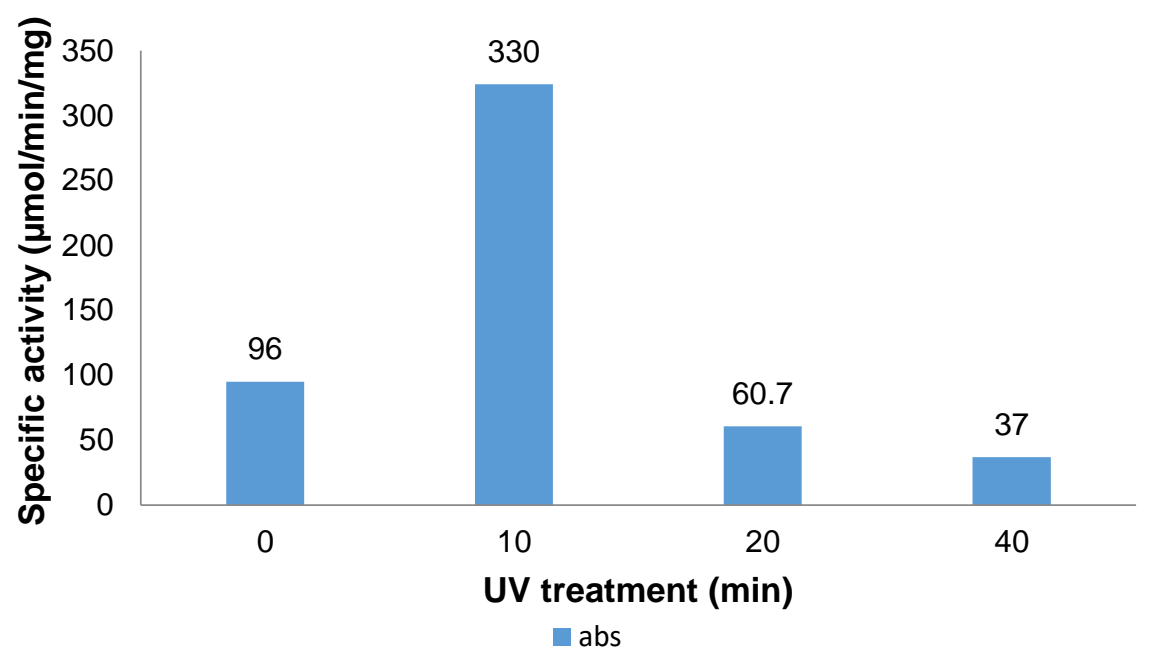

Fig. 1. Comparison of cellulase production after UV mutagenesis of $A$. niger. The UV treatment for 10 min yielded maximum cellulase production.

\section{RNA Extraction}

The culture showing maximum activity after combined treatment was selected for RNA extraction. As compared to the kit method, manual extraction of RNA using Trizol reagent yielded a better concentration of mRNA. Total fungal RNA was visualized on a $0.8 \%$ agarose gel under UV light as shown in Fig. 2.

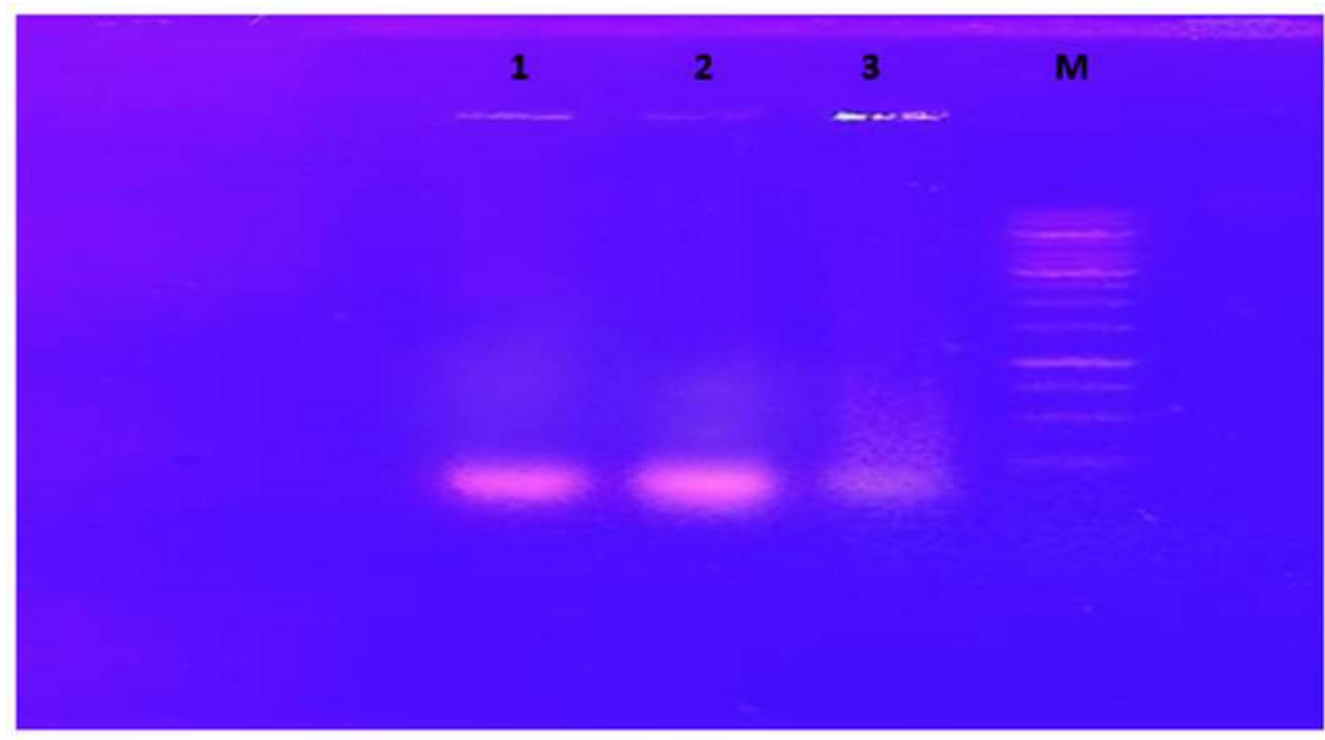

Fig. 2. Agarose gel electrophoresis of total RNA of $A$. niger UMMT-I using Trizol Reagent with liquid nitrogen (lanes 1-3). M: 1 kb DNA Ladder (Fermentas)

\section{Amplification and Cloning of Mutated Cellulase Gene}

The amplified cellulase gene was approximately $1000 \mathrm{bp}$ in length (Fig. 3). The gene was purified and sequenced commercially. After ligation and transformation, white colonies were positive transformants in which the mutant cellulase gene was successfully transformed (Fig. 4). Plasmid DNA was purified from the positive transformants. 


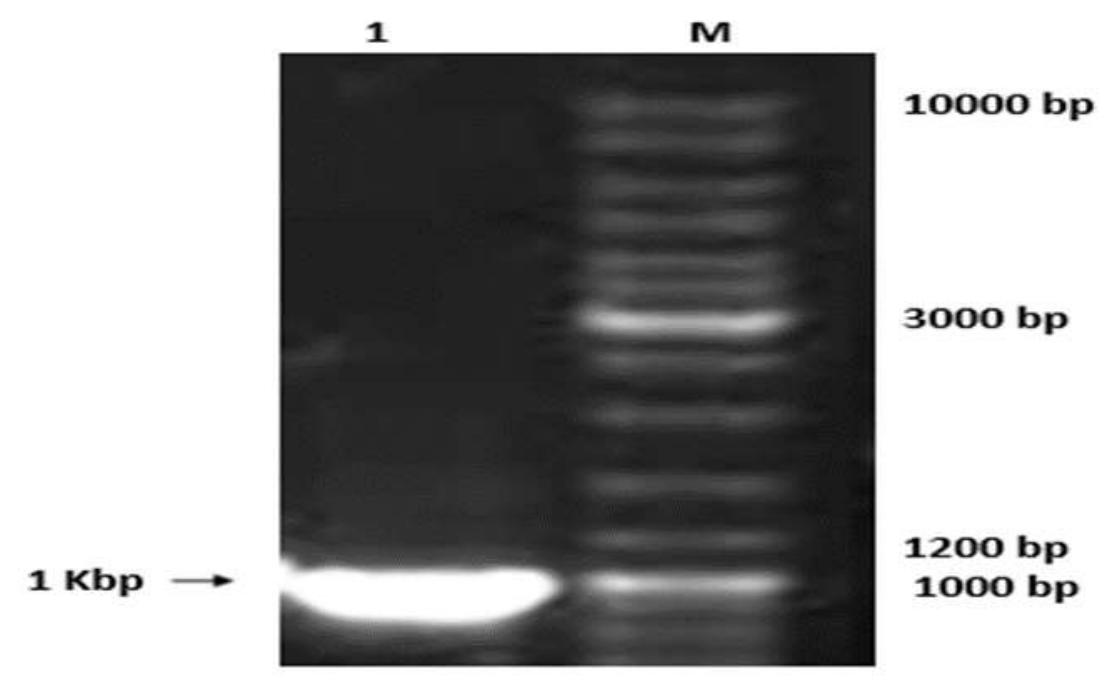

Fig. 3. Agarose gel electrophoresis of amplification of cellulase gene from A. niger mutant

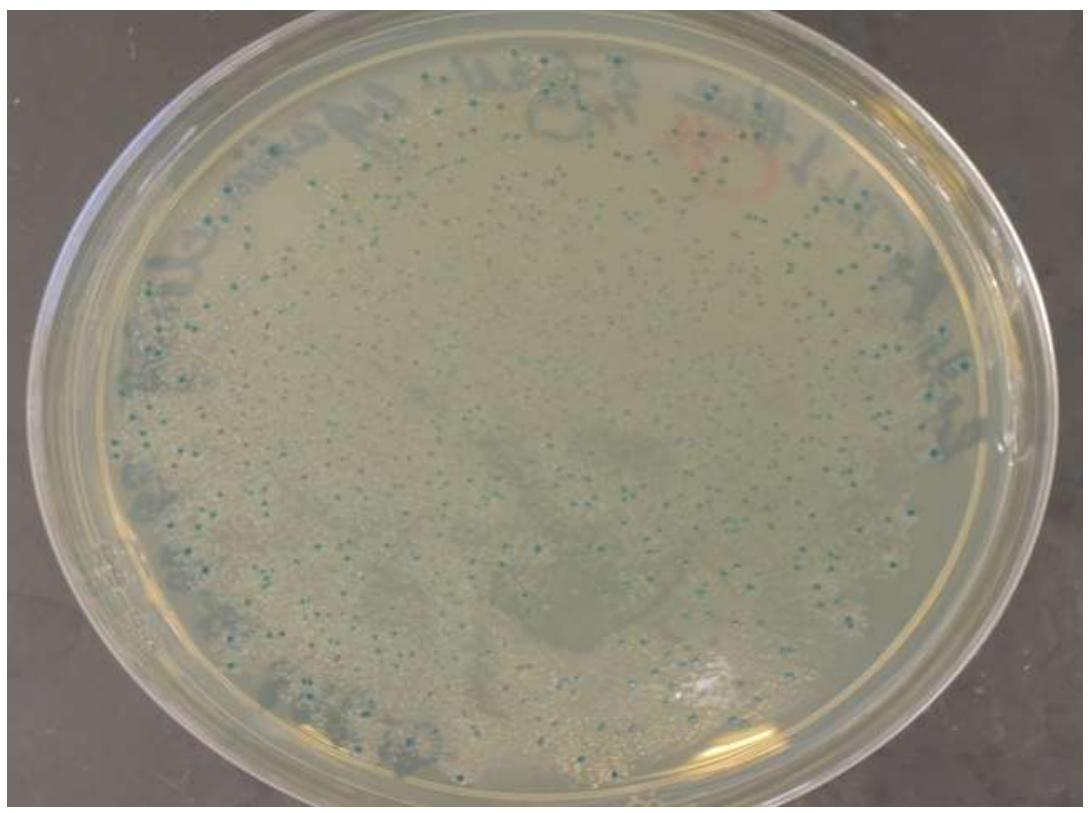

Fig. 4. Blue/White Screening of positive transformants

The purified pTZ57R/T cloning vector was digested with the NdeI and EcoRI restriction enzymes. The products are shown in Fig. 5. The $2.8 \mathrm{~kb}$ band represented the vector, and the $1 \mathrm{~kb}$ band was the mutant cellulase gene.

The size of cellulase gene from mutant A. niger in this study was $1000 \mathrm{bp}$. Rungrattanakasin et al. (2018) amplified a mutant endoglucanase gene from A. fumigatus, and their amplified product was $1383 \mathrm{bp}$ in length, resulting in a polypeptide of 460 amino acid. Dashtban et al. (2009) produced thermostable $\beta$-glucosidase gene from fungus Periconia sp. An alkaline protease gene of $747 \mathrm{bp}$ from A. niger was reported by Kerrien et al. (2011). 


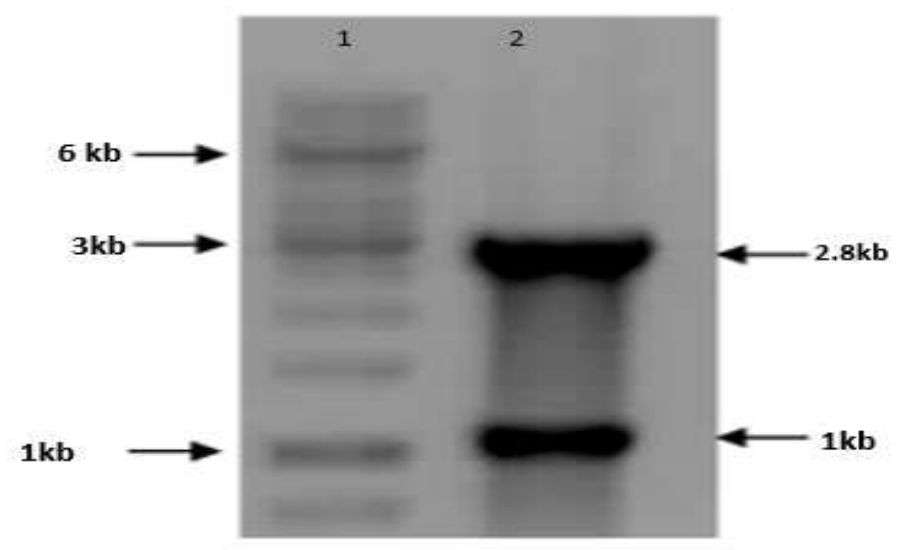

Fig. 5. Agarose Gel Electrophoresis of Restriction Digest

\section{Comparison of Cellulase Production}

Statistical analysis through ANOVA gave $\mathrm{p}<0.01$, indicating a highly significant difference in the production of cellulase by the wild type A. niger, A. niger UVMT-I, and recombinant $E$. coli. DMRT further confirmed that specific activity of cellulase by recombinant E. coli was the highest (441 $\mu \mathrm{mol} / \mathrm{min} / \mathrm{mg}$ ), followed by the A. niger UVMT-I $(330 \mu \mathrm{mol} / \mathrm{min} / \mathrm{mg})$ and the wild type A. niger $(96 \mu \mathrm{mol} / \mathrm{min} / \mathrm{mg})$. Figure 6 shows the cellulase production by the three strains, showing the highest cellulase activity by the recombinant E. coli. Gao et al. (2015) also engineered a recombinant cellulase utilizing $E$. coli on the basis of heterologous cellulase secretion system. This recombinant was capable to produce biofuels and biochemicals directly from cellulose. Similarly, Said et al. (2017) observed doubled cellulase activity from recombinant E.coli as compared to wild type. In accordance with our findings, Dennis et al. (2017) also observed that enzyme activity of recombinant cellobiohydrolase II isolated from Trichoderma reesei and expressed in $W$. anomalus was more than native enzyme. Hence, E. coli strains engineered with recombinant genes can produce better yield of enzymes as compared to native ones.

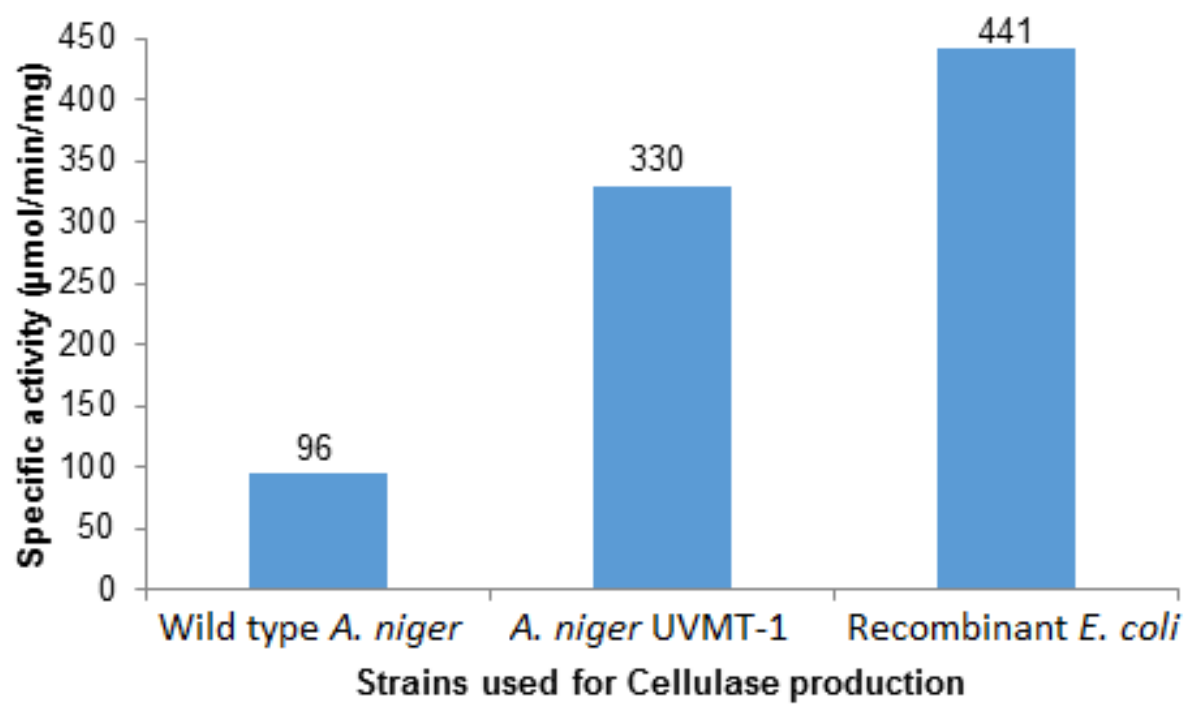

Fig. 6. Cellulase production by three strains. The recombinant E.coli showed maximum cellulase activity among all strains 


\section{CONCLUSIONS}

1. The increased production of cellulase by A. niger UVMT-I was further enhanced by the cloning and expression of mutated cellulase gene in E. coli.

2. Recombinant E. coli engineered with mutated cellulase gene is a potent source of cellulase production which can be applied in the different industries to overcome the increasing demand of the cellulolytic enzymes.

\section{ACKNOWLEDGEMENT}

This research work was performed utilizing the funding of National Research Program for Universities (NRPU) Project No 6485 (Higher Education Commission, Government of Pakistan) entitled "Hyper expression and characterization of mutant cellulase enzyme from indigenous strain of Aspergillus niger."

\section{REFERENCES CITED}

Chand, P., Aruna, A., Maqsood, A. M., and Rao, L. V. (2005). "Novel mutation method for increased cellulase production," Journal of Applied Microbiology 98(2), 318-323. DOI: 10.1111/j.1365-2672.2004.02453.x

Dashtban, M., Schraft, H., and Qin, W. (2009). "Fungal bioconversion of lignocellulosic residues; Opportunities and perspectives," International Journal of Biological Sciences 5(6), 578-595. DOI: 10.7150/ijbs.5.578

Dennis, J., Díaz-Rincón., Ivonne, D., Erika, O., Alexander, R., Angela, E., Claudia, M., Parra-Giraldo., Raúl, A., Poutou-Piñales., Carlos, J., Alméciga-Díaz, and Balkys, Q. H. (2017). "Production of recombinant Trichoderma reesei cellobiohydrolase II in a new expression system based on Wickerhamomyces anomalus," Enzyme Research. DOI: $10.1155 / 2017 / 6980565$

Gao, D., Luan, Y., Wang, Q., and Qi., Q. (2015). "Construction of celluloseutilizing Escherichia coli based on a secretable cellulase," Microbial Cell Factories 14(159). DOI: 10.1186/s12934-015-0349-7

Hadri, S. H., Asad, M. J., Hyder, M. Z., Naqvi, S. M. S., Mukhtar, T., Zafar, M., Shah, S. H., Mehmood, R. T., and Wu, J. D. (2019). "Characterization of a novel thermophilic endopolygalacturonase produced by Bacillus licheniformis IEB-8 BioResources 14(2), 2873-2884. DOI: 10.15376/biores.14.2.2873-2884

Hadri, S. H., Asad, M. J., Hyder, M. Z., Naqvi, S. M. S., Mukhtar, T., Memhmood, R. T., and Wu, J. D. (2018). "Response surface methodology for the production of endopolygalacturonase by a novel Bacillus licheniformis," Advancements in Life Sciences 5(4), 204-210.

Kerrien, S., Aranda, B., Breuza, L., Bridge, A., Broackes-Carter, F., Chen, C., Duesbury, M., Dumousseau, M., Feuermann, M., Hinz, U., Jandrasits, C., Jimenez, R.C., Khadake, J., Mahadevan, U., Masson, P., Pedruzzi, I., Pfeiffenberger, E., Porras, P., Raghunath, A., Roechert, B., Orchard, S., and Hermjakob, H. (2011). "The IntAct molecular interaction database in 2012," Nucleic Acids Research 40 (Database issue), D841-D846. DOI: 10.1093/nar/gkr1088 
Kramer, S. J., and Pochapin, M. B. (2012). "Gastric phytobezoar dissolution with ingestion of Diet Coke and cellulose," Gastroenterology and Hepatology 8(11), 770.

Mancuso, M., Salviati, L., Sacconi, S., Otaegui, D., Camano, P., Marina, A., Bacman, S., Moraes, C.T., Carlo, J.R., Garcia, M., Garcia-Alvarez, M., Monzon, L., Naini, A.B., Hirano, M., Bonilla, E., Taratuto, A. L., DiMauro, S., and Vu, T. H. (2002).

"Mitochondrial DNA depletion: Mutations in thymidine kinase gene with myopathy and SMA," Neurology, 59(8), 1197-1202.

Nahideh, J., Jafarizadeh, H., Hamzeh-Mivehroud, M., and Adibpour, M. (2017).

"Optimization of UV irradiation mutation conditions for cellulase production by mutant fungal strains of Aspergillus niger through solid state fermentation," Green

Processing and Synthesis, 6(3), 333-340. DOI: 10.1515/gps-2016-0145

Rajeshkumar, J., and Ilyas, M. M. (2011). "Production of phophatase by mutated fungal strains," International Multidisciplinary Research Journal 1(5), 23-29.

Ramzan, M., and Mehmood, T. (2009). "Enhanced production of glucose oxidase from UV mutant of Aspergillus niger," African Journal of Biotechnology 8(2), 288-290. DOI: 10.4314/ajb.v8i2.59791

Rungrattanakasin, B., Premjet, S., Thanonkeo, S., Klanrit, P., and Thanonkeo, P. (2018). "Cloning and expression of an endoglucanase gene from the thermotolerant fungus Aspergillus fumigatus DBiNU-1 in Kluyveromyces lactis," Brazilian Journal of Microbiology 49(3), 647-655. DOI: 10.1016/j.bjm.2017.10.001

Saini, R., Saini, J. K., Adsul, M., Patel, A. K., Mathur, A., Tuli, D., and Singhania, R. R. (2015). "Enhanced cellulase production by Penicillium oxalicum for bio-ethanol application," Bioresource Technology 188, 240-246. DOI: 10.1016/j.biortech.2015.01.048

Said, Z. A., Lina, P. A., Heri, H., Siswa, S., Siti, F. R., Don-Hee, P., and Misri, G. (2017). "Production and characterization of cellulase from E. coli EgRK2 recombinant based oil palm empty fruit bunch," Biotechnology and Bioprocess Engineering 22(3), 287295

Singhania, R. R., Sukumaran, R. K., Patel, A. K., Larroche, C., and Pandey, A. (2010). "Advancement and comparative profiles in the production technologies using solidstate and submerged fermentation for microbial cellulases," Enzyme and Microbial Technology 46(7), 541-549. DOI: 10.1016/j.enzmictec.2010.03.010

Stein, B., Rahmsdorf, H., Steffen, A., Litfin, M., and Herrlich, P. (1989). "UV-induced DNA damage is an intermediate step in UV-induced expression of human immunodeficiency virus type 1, collagenase, c-fos, and metallothionein," Molecular and Cellular Biology 9(11), 5169-5181. DOI: 10.1128/mcb.9.11.5169

Tolonen, A. C., Cerisy, T., El-Sayyed, H., Boutard, M., Salanoubat, M., and Church, G. M. (2015). "Fungal lysis by a soil bacterium fermenting cellulose," Environmental Microbiology, 17(8), 2618-2627. DOI: 10.1111/1462-2920.12495

Rahman, M. (2017). "Antimycotic activity of essential oil of Rosmarinus officinalis on asexual reproductive stages of foodstuff fungi," International Journal of Pure and Applied Bioscience 5(5), 1-9. DOI: 10.18782/2320-7051.5899

Van, H. V., Tuan, A. P., and Keun, K. (2011). "Improvement of fungal cellulase production by mutation and optimization of solid state fermentation," Mycobiology 39(1), 20-25. DOI: 10.4489/myco.2011.39.1.020

Yamada, R., Kashihara, T., and Ogino, H. (2017). "Improvement of lipid production by the oleaginous yeast Rhodosporidium toruloides through UV mutagenesis," World 
Journal of Microbiology and Biotechnology 33(5), 99. DOI: 10.1007/s11274-0172269-7

Zafar, M., Ahmed, S., Khan, M. I. M., and Jamil, A. (2014). "Recombinant expression and characterization of a novel endoglucanase from Bacillus subtilis in Escherichia coli," Molecular Biology Reports 41(5), 3295-3302. DOI:10.1007/s11033-014-3192-8

Zhang, L., Fan, Y., Zheng, H., Du, F., Zhang, K, Huang, X., Wang, L., Zhang, M., and Niu, Q. (2013). "Isolation and characterization of a novel endoglucanase from a Bursaphelenchus xylophilus metagenomic library," Plos One 8(12), e82437. DOI: 10.1371/journal.pone.0082437

Article submitted: May 3, 2019; Peer review completed: July 29, 2019; Revised version received: August 29, 2019; Accepted: September 8, 2019; Published: September 27, 2019.

DOI: $10.15376 /$ biores.14.4.9054-9063 